Art and the City 



\section{Art and the City}

\section{Civic Imagination and Cultural Authority in Los Angeles}

SARAH SCHRANK

\section{$\overline{\text { PENN }}$}

University of Pennsylvania Press

Philadelphia 
Copyright (C) 2009 University of Pennsylvania Press

All rights reserved. Except for brief quotations used for purposes of review or scholarly citation, none of this book may be reproduced in any form by any means without written permission from the publisher.

Published by

University of Pennsylvania Press

Philadelphia, Pennsylvania 19104-4112

Printed in the United States of America on acid-free paper

10987654321

Library of Congress Cataloging-in-Publication Data

Schrank, Sarah.

Art and the city : civic imagination and cultural authority in Los Angeles / Sarah Schrank.

p. $\mathrm{cm}$.

Includes bibliographical references and index.

ISBN 978-0-8122-4117-4 (alk. paper)

1. Public art-Political aspects-California-Los Angeles. 2. Art and societyCalifornia-Los Angeles. 3. Los Angeles (Calif.)—Cultural policy. I. Title. N8845.L67S37 2008

$701^{\prime} .030979494-\mathrm{dc} 22$

2008012685 
For Bill, Bernice, Joe, and Rachel 
